Journal of Immunogenetics (1975) 2, 389-401.

\title{
THE EXPRESSION OF H-2K, H-2D AND Ia ANTIGENS IN VARIOUS TISSUES AS ASSESSED IN FC RECEPTOR INHIBITION SYSTEMS
}

\author{
P. Halloran, V. Schirrmacher, Chella S. David and \\ N. A. Staines \\ The Tissue Immunology Research Unit, London Hospital Medical College, London, England; \\ The Department of Human Genetics, University of Michigan Medical School, Ann Arbor, \\ Michigan, U.S.A, and Searle Research Laboratories, High Wycombe, Bucks, England.
}

(Received 1 July 1975)

\section{SUMMARY}

The ability of mouse alloantibody to inhibit EA rosette formation and antibodydependent cell-mediated cytotoxicity (ADCC) was used to study the expression of $\mathrm{H}-2 \mathrm{~K}$, Ia and $\mathrm{H}-2 \mathrm{D}$ antigens in various tissues. As previously reported antisera against each of these groups of antigens inhibited B lymphocyte EA rosette formation. Continuing studies confirmed these observations but established that quantitative differences may exist in the ease with which antibody against antigens in each region can inhibit EA rosettes: anti $\mathrm{H}-2 \mathrm{D}$ and anti-la seemed stronger relative to their cytotoxic titres than anti $\mathrm{H}-2 \mathrm{~K}$. Possible reasons for this are discussed. When rosette forming cells from other tissues were studied, (bone marrow cells, peritoneal macrophages and tumour cells), they were inhibited by anti $\mathrm{H}-2 \mathrm{~K}$ and anti $\mathrm{H}-2 \mathrm{D}$ sera but not by anti Ia sera, presumably reflecting the restricted distribution of Ia antigens in those tissues.

Inhibition of ADCC by various antisera reflected qualitatively and quantitatively the expression of $\mathrm{H}-2$ antigens in various tissues: whereas effector cell activity in spleen, bone marrow, or peritoneal cell populations was inhibited by anti $\mathrm{H}-2$ or anti-Ia sera, the amount of inhibition observed with anti-Ia was much less when the tissue expressed little Ia antigen (bone marrow) than when it expressed abundant Ia antigen (spleen). The ability of cytotoxicity inhibition to detect antibody coated cells was used to assess the relative amount of Ia antigen on thymus and on lymph node cells, showing significant amounts of Ia antigen on thymus cells. Fc receptor inhibition studies may thus be useful as new approaches to the study of the expression of the antigens of the major histocompatibility complex.

\section{INTRODUCTION}

Fc receptors and their relationships with membrane alloantigens are natural sources of interest to the immunogeneticist. The ability of antibody against a wide variety of cell

Address for reprints: Dr P. Halloran, Tissue Immunology Research Unit, The London Hospital Medical College, London, E1 2AD, England. 
surface antigens to inhibit $\mathrm{Fc}$ receptor binding (and particularly the ability of anti-Ia to inhibit binding of aggregated immunoglobulin by the Fc receptor (Dickler \& Sachs, 1974)) has greatly stimulated studies in this field. In addition to providing information about possible antigenic associations of the $\mathrm{Fc}$ receptor, such studies can provide methodology to study properties of the cell surface antigens themselves. The present report will show that $\mathrm{Fc}$ receptor dependent assays can be used to obtain information about the expression of cell surface antigens in various tissues.

We have been studying the inhibitory action of antibody in each of two Fc receptor dependent assays: (i) EA rosettes, in which Fc receptor bearing cells (usually B lymphocytes) form rosettes with antibody-coated erythrocytes; (ii) antibody-dependent cellmediated cytotoxicity ( $\mathrm{ADCC}$ ), in which cytotoxic effector cells bearing $\mathrm{Fc}$ receptors lyse antibody-coated ${ }^{51} \mathrm{Cr}$-labelled target cells. In EA rosettes, antibody against antigens on the surface of the rosette forming cell (RFC-in our previous studies usually B lymphocytes) inhibited EA rosette formation (Schirrmacher et al., 1975a; Halloran et al., 1975). Antibodies against $H-2$ antigens (in the $K, I$ and $D$ regions), a non $H-2$ antigen (Ly 4.2), mouse immunoglobulin (MIg), and mouse B lymphocyte antigen (MBLA) were inhibitory. Although the precise mechanism of inhibition was obscure, the strong inhibition produced by the $F\left(a^{\prime}\right)_{2}$ portions of the antibodies showed that the $F c$ portions of the antibody were not involved. Steric hindrance of cell contact was a possible explanation of the inhibition (for discussion see Halloran et al., 1975; Schirrmacher \& Halloran, 1975).

In ADCC, antibody against any cell surface antigens in the incubation mixture can form antibody-cell complexes which compete with the antibody-coated target cell for the $\mathrm{Fc}$ receptors of the cytotoxic effector cell, producing competitive inhibition of cytotoxicity (Halloran \& Festenstein, 1974; Halloran et al., 1974; Schirrmacher et al., 1975b). Antibodies against a wide variety of surface components $(\mathrm{H}-2 \mathrm{~K}, \mathrm{H}-2 \mathrm{D}$, Ia, non H-2, MIg, MBLA, brain associated theta (BA $\theta$ )) have all produced specific inhibition. Interestingly, however, no antibody yet tested has inhibited the Fc receptors of cytotoxic effector cells by binding directly to antigens associated with the $F c$ receptor (i.e. the $F\left(a b^{\prime}\right)_{2}$ portions of these antibodies never produced inhibition) (Schirrmacher et al., 1975a and b).

The present studies were undertaken to assess whether these Fc receptor inhibition systems would reflect the expression of cell surface antigens on cells other than spleen and lymph node cells. Since the H-2K and H-2D antigens would be present on all tissues, we first sought to establish more information about the $\mathrm{K}$ and $\mathrm{D}$ region antigens which were detected in EA rosette inhibition: were these the same antigens as are expressed on erythrocytes, and could we assess quantitatively the potency of antibody to these antigens compared with antibody against Ia antigens in EA rosette inhibition? Having established these points, we sought to assess the expression of $\mathrm{H}-2 \mathrm{~K}$, Ia and $\mathrm{H}-2 \mathrm{D}$ region antigens on various tissues by inhbition of EA rosettes and ADCC. Finally, we assessed the relative amounts of Ia antigen on thymus and lymph node cells quantitatively by cytotoxicity inhibition, to illustrate how the use of this technology could contribute to the understanding of a current immunogenetic problem.

\section{MATERIALS AND METHODS}

Eagle's minimal essential medium (The Wellcome Trust Research Laboratories, Kent, England) with $0.02 \mathrm{M}$ Hepes (Wellcome), gentamycin $(5 \mu \mathrm{g} / \mathrm{ml})$, and $5 \%$ fetal calf serum 
(Flow Laboratories, Inc., Rockville, Maryland, U.S.A.) was used. Rosette assays were done in $63.5 \times 9.5 \mathrm{~mm}$ round bottomed polystyrene tubes (LP/3 tubes, Luckham Limited, Burgess Hill, Sussex, England). Cytotoxicity assays were done in $44 \mathrm{~mm} \times 9 \mathrm{~mm}$ polystyrene tubes (The Metal Box Co., Surrey, England). Radioactive sodium chromate $\left({ }^{51} \mathrm{Cr}\right.$ ) was obtained from the Radiochemical Centre, Amersham, England.

C57B1/10.ScSn (B10), B10.A, B10.D2/n, B10.BR, B10.A(5R) BALB/c, CBA/H, and $\mathrm{DBA} / 2$ mice were bred in the London Hospital Medical College from breeding pairs obtained from the Laboratory Animal Centre, Carshalton, Surrey, England. Antisera were prepared by repeated weekly intraperitoneal injection of spleen cells. With antiserum (B10. $\times$ B10.A)F1 anti B10.D2 and B10.D2 anti B10.A, absorption with red cells, (from which the leucocytes had been removed by centrifugation), was performed, and the absorbed antibody was re-eluted by acid treatment as described elsewhere (Staines, et al. 1975). This procedure eliminated any Ia antibody from the serum.

The activity of these antibodies was determined in a ${ }^{51} \mathrm{Cr}$ release assay as described by Sanderson (1965) and Wigzell (1965), and in a complement-dependent microcytotoxicity assay under phase contrast microscopy (Halloran et al., 1974). Serum A.TH anti A.TL was prepared and tested as previously described (David et al., 1973). Details of the specificity of the antisera employed are found in Table 1.

TABLE 1. Specificity of anti $\mathbf{H}-2$ sera used

\begin{tabular}{|c|c|c|c|c|}
\hline \multirow[t]{2}{*}{ Designation } & \multirow[t]{2}{*}{ Description } & \multicolumn{3}{|c|}{$\mathrm{H}-\mathbf{2}$ and Ia activities * } \\
\hline & & $\mathrm{H}-2 \mathrm{~K}$ & $\mathrm{Ia}$ & $\mathrm{H}-2 \mathrm{D}$ \\
\hline Anti $\mathrm{H}-2 \mathrm{~K} .23$ & A.TL anti A.AL & $23,8,11$ & - & 一 \\
\hline Anti $\mathrm{H}-2 \mathrm{~K} .23$ eluate $\dagger$ & B10.D2 anti B10.A & $\begin{array}{l}23,1,5,11 \\
\text { others }\end{array}$ & - & 1 \\
\hline Anti H-2K. $31 \S$ & $(\mathrm{B} \times \mathrm{A}) \mathrm{F} 1$ anti B10.D2 & 31 & 11,16 & - \\
\hline Anti H-2K.31 eluate $\dagger$ & $(\mathrm{B} \times \mathrm{A}) \mathrm{F} 1$ anti $\mathrm{B} 10 . \mathrm{D} 2$ & 31 & - & - \\
\hline Anti $\mathrm{H}-2 \mathrm{~K} .33 \S$ & $(\mathrm{B} 10 . \mathrm{D} 2 \times \mathrm{A}) \mathrm{F} 1$ anti $\mathrm{B} 10 . \mathrm{A}(5 \mathrm{R})$ & 33 , others & 9 & - \\
\hline $\begin{array}{l}\text { Anti } H-2 K .8 \S \\
\text { Anti } H-2 K D .1 \S\end{array}$ & $\begin{array}{l}(\mathrm{B} 10 \times \mathrm{A} . \mathrm{SW}) \mathrm{F} 1 \text { anti B10.M } \\
(\mathrm{C} 3 \mathrm{H} . \mathrm{SW} \times \mathrm{HTG}) \mathrm{F} 1 \text { anti }\end{array}$ & $8,9,3,7$ & 1,14 & - \\
\hline & C 3 H.OH & 1 & - & 1,32 \\
\hline $\begin{array}{l}\text { Anti H-2D.4 } \S \ddagger \\
\text { Anti H-2D.4, } 13\end{array}$ & $\begin{array}{l}(\mathrm{B} 10 . \mathrm{AKM} \times 129) \mathrm{F} 1 \text { anti B10.A } \\
(\mathrm{B} 10 \times \mathrm{C} 3 \mathrm{H} . \mathrm{OL}) \mathrm{F} 1 \text { anti }\end{array}$ & - & - & 4 \\
\hline & $\mathrm{B} 10 . \mathrm{A}(5 \mathrm{R})$ & - & - & $4,13,42$ others \\
\hline Anti H-2D.13 $\S$ & $(\mathrm{B} 10 \times$ LP.RIII)F1 anti B10.A(5R) & - & 15 & $4,13,42$ others \\
\hline Anti Ia $1,2,3,7,15$ & A.TH anti A.TL & - & $1,2,3,7,15$ & - \\
\hline Anti Ia $1,2,3$ & $(\mathrm{~A} . \mathrm{TH} \times \mathrm{D} 2) \mathrm{F} 1$ anti $\mathrm{A} . \mathrm{TL}$ & - & $1,2,3$ & - \\
\hline
\end{tabular}

* For H-2 chart see Démant et al. 1973; for Ia specificities 1-10 see Shreffer \& David 1975; Ia 11 to 16, David, unpublished data. Activity against $\mathbf{S}$ region gene products is a theoretical possibility in many of these antisera, as is activity against $G$ region products (David et al., 1975; Klein et al., 1975).

$\dagger$ Prepared by absorption to appropriate mouse erythrocytes, and subsequent acid elution from the erythrocytes, thus removing anti Ia activity.

¥ Ia 6 could be present in this antiserum but is not demonstrable. (P. Halloran unpublished; M. Hess, personal communication).

$\S$ These antisera were obtained from the Transplantation Immunology Branch, N.I.A.I.D., NIH, Bethesda, Maryland. Details of the raising and testing of these sera are contained in NIH catalogue and its 1973 and 1974 supplements (Snell, 1968). 
Details of the production of rabbit anti chicken erythrocyte serum and the preparation of its IgG fraction have been described previously (Halloran et al., 1974). Rabbit anti-ox erythrocyte serum was a gift of Dr A. Munro, Department of Pathology, Cambridge, England.

Mouse thymocyte suspensions were prepared by teasing thymus tissue, from which parathymic lymph nodes had been dissected, through a fine stainless steel mesh. Spleen and lymph node cell suspensions were prepared in a similar way. Bone marrow cells were prepared by irrigating the femoral marrow cavities with heparinized medium. Peritoneal cells were prepared by irrigation of the peritoneal cavities with $5 \mathrm{ml}$ of medium. When 'activated' peritoneal cells were to be tested, the animals were injected intraperitoneally 48 hr previously with $4 \mathrm{ml}$ of fetal bovine serum.

Details of the preparation of EA rosettes and their inhibition by anti $\mathrm{H}-2$ antisera are published elsewhere (Halloran et al., 1975). In brief, the suspension of mouse cells (3-6× $10^{6} / \mathrm{ml}$ ) to be assessed was first preincubated with normal mouse serum or antiserum, for 30 min at room temperature; the cells were washed once, and centrifuged at $4^{\circ} \mathrm{C}$ with a $2 \%$ suspension of chicken erythrocytes coated with rabbit anti-chicken erythrocyte gamma globulin. The cells were resuspended, and the percentage rosette-forming cells was counted in a Neubauer chamber. At least 600 mouse cells were usually examined for rosettes.

Details of the cytotoxicity inhibition assay (CIA) methodology have been published elsewhere (Halloran et al., 1974). In brief, the usual cytotoxicity system consisted of mouse spleen, bone marrow, or peritoneal cells (cytotoxic effector cells), ${ }^{51} \mathrm{Cr}$-labelled chicken erythrocytes (CRBC), and minute amounț of rabbit antiserum against chicken erythrocytes (RACA). The antiserum to be tested was added either directly, or was first preincubated with another population of mouse cells and these washed 'antibody-cell complexes' were added. In these experiments either a $4 \mathrm{hr}$ protocol (using $2 \times 10^{6}$ spleen cells, $10^{4} \mathrm{CRBC}$ and $1 / 50,000 \mathrm{RACA}$ ) or an $18 \mathrm{hr}$ protocol (106 spleen cells, $2 \times 10^{4} \mathrm{CRBC}$, and $1 / 100,000 \mathrm{RACA}$ ) was used. Incubations were done at $37^{\circ} \mathrm{C}$ in a $5 \% \mathrm{CO}_{2}, 10 \% \mathrm{O}_{2}$ atmosphere. At the end of the incubation period, the tubes were centrifuged; aliquots were removed and counted in a Packard Autogamma well-type scintillation counter and the percent ${ }^{51} \mathrm{Cr}$ release was determined. All samples were done in triplicate and the means and standard deviations were determined.

\section{RESULTS}

\section{Quantitative comparisons of antibody against $K, I$ or $D$ region antigens in EA rosette inhibition}

Our previous observations that anti $\mathrm{H}-2$ sera specifically inhibited EA rosette formation raised several questions: (i) were antibodies against $\mathrm{K}, \mathrm{I}$ and $\mathrm{D}$ region antigens all active in this inhibition? (ii) if so, did the antibodies against $K$ and $D$ region antigens recognise the $\mathrm{H}-2 \mathrm{~K}$ and $\mathrm{D}$ serologically detectable antigens as expressed on red cells? (iii) are there quantitative differences between the efficiency of antibodies against $\mathrm{K}$, I or $\mathrm{D}$ region antigens in producing rosette inhibition?

The first question has already been examined in detail (Halloran et al., 1975) and we here add the observation that 'anti H-2K.23' serum (A.TL anti A.AL) inhibits rosette formation (Fig. 1, Table 2). Thus antibodies against $\mathrm{K}, \mathrm{I}$ or $\mathrm{D}$ region antigens clearly can inhibit rosette formation. But are the $\mathrm{K}$ and $\mathrm{D}$ region antigens the same as those on red cells? To resolve this we tested antisera absorbed to red cells and subsequently re-eluted to remove 


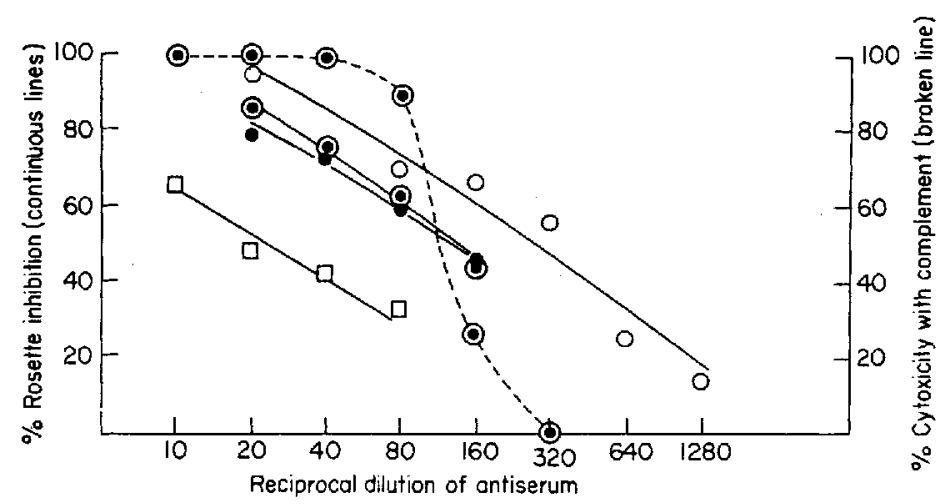

FIG. 1. Comparison of the titration curves of various antisera in EA rosette inhibition (continuous lines) with a typical complement-dependent lysis titration curve from an anti $\mathrm{H}-2$ serum (broken line). The antisera shown are anti $\mathrm{Ia}, 1,2,3,(0)$, anti $\mathrm{H}-2 \mathrm{~K} .23$ eluate (•), anti H-2D.4 (O), and anti H-2K.23 (口). The 50\% rosette inhibition titre was determined from such curves by extrapolation. The complement dependent lysis titre was the mean of two experiments in which highest dilution producing detectable lysis was determined.

TABLE 2. Comparison of various anti $\mathrm{H}-2$ sera for strength in complement dependent cytotoxicity and EA rosette inhibition

\begin{tabular}{|c|c|c|c|c|}
\hline Antiserum & $\begin{array}{l}\text { Strain } \\
\text { tested }\end{array}$ & CDL titre * & $\begin{array}{c}\text { EA rosette } \dagger \\
\text { inhibition titre }\end{array}$ & $\begin{array}{c}\text { Ratio of EA } \\
\text { rosette } \\
\text { inhibition titre } \\
\text { to CDL titre }\end{array}$ \\
\hline Anti Ia $1,2,3,7,15$ & B10.BR & $1 / 5000$ & $1 / 2400$ & 0.48 \\
\hline Anti Ia.1, 2, 3 & B10.BR & $1 / 1600$ & $1 / 350$ & $0 \cdot 22$ \\
\hline Anti H-2D.4 & A.TH & $1 / 320$ & $1 / 120$ & 0.37 \\
\hline Anti H-2D. 4,13 & A.TH & $1 / 640$ & $1 / 320$ & 0.50 \\
\hline Anti H-2KD.1 & B10.BR & $1 / 1280$ & $1 / 320$ & 0.25 \\
\hline Anti $\mathbf{H}-2 \mathrm{~K} .23$ & B10.BR & $1 / 320$ & $1 / 20$ & 0.06 \\
\hline Anti $\mathbf{H}-2 \mathrm{~K} .23$ eluate & B10.BR & $1 / 1280$ & $1 / 120$ & 0.09 \\
\hline Anti $\mathrm{H}-2 \mathbf{K} .31$ eluate & B10.D2 & $1 / 40$ & $1 / 5$ & 0.12 \\
\hline
\end{tabular}

* Highest dilution giving detectable lysis, using guinea pig complement.

$\dagger$ Determined by extrapolation from where the serial dilution curve crossed the $50 \%$ inhibition line plotted as shown in Fig. 1.

anti-Ia antibody. These experiments, shown in Table 2 and Fig. 1, demonstrate that these eluates continued to show specific activity in rosette inhibition. Thus the $\mathrm{H}-2 \mathrm{~K}$ antigens (and presumably the H-2D antigens as well) seem to be the same as those found on red cells, and therefore probably represent the usual serologically detectable $\mathrm{H}-2 \mathrm{~K}$ antigens.

But quantitative differences in the inhibitory potency of anti $\mathrm{H}-2 \mathrm{~K}$, anti $\mathrm{H}-2 \mathrm{D}$ and antiIa antibody might still exist. To investigate this we compared the strength of the rosette inhibitory activity with the strength of the cytotoxic activity in various antisera. We determined the titre producing $50 \%$ inhibition of EA rosette formation (because of its relative objectivity) and compared this with the highest titre producing detectable cytotoxicity in 
CDL. Typical titration curves obtained in both assays are shown in Fig. 1 . There was an obvious difference between the curves produced with the two techniques: the more gentle uniform curve produced in rosette inhibition, $v$. the steeper curve of cytotoxicity, may have implications for our understanding of the mechanisms involved. When the $50 \%$ inhibition titre was determined from curves like these and divided by the maximal CDL titre, the quotient reflected the amount of inhibitory activity per unit of cytotoxic activity present, as shown in Table 2. The anti-Ia and anti H-2D sera were considerably stronger than the anti $\mathrm{H}-2 \mathrm{~K}$ serum and the eluates. Possible explanations for and implications of these observations will be discussed.

The expression of $K, I$ and $D$ region antigens on $F c$ receptor bearing cells derived from various tissues

(a) EA rosette inhibition studies. We previously established that RFC's were inhibited by antisera against a wide variety of antigens expressed on their surfaces. This characteristic provided a potential system for studying the cell surface antigens expressed on various types of RFC, such as bone marrow cells, peritoneal macrophages, and tumour cells. As shown in Table 3, bone marrow RFC's were strongly inhibited by antibody against their $\mathrm{K}$ and $\mathrm{D}$ region antigens but not by antibody against $\mathrm{I}$ region antigens or $\mathrm{MIg}$, agreeing with previous observations using bone marrow cells (Halloran et al., 1975). Table 3 also illustrates that ox red cells (ORBC) coated with rabbit anti-ox antibody can be substituted for chicken red cells (CRBC) as EA. Experiments with ox erythrocytes as EA tested in parallel with the usual CRBC EA have shown remarkably similar results in EA rosette inhibition (P. Halloran, unpublished observations) and ORBC have been substituted for CRBC in some experiments.

TABLE 3. Inhibition of EA-RFC * from different tissues: bone marrow cells

\begin{tabular}{|c|c|c|c|c|c|}
\hline \multirow[b]{2}{*}{ Antiserum } & & \multicolumn{2}{|c|}{$\mathrm{BALB} / \mathrm{c}$} & \multicolumn{2}{|c|}{$\mathrm{CBA} / \mathrm{H}$} \\
\hline & & $\%$ EA-RFC $\%$ & Inhibition & $\%$ EA-RFC $\%$ & Inhibition \\
\hline 一 & & $34 \cdot 5 \pm 1 \cdot 4$ & & $30.7 \pm 0.5$ & \\
\hline Anti H-2D.4 & $1: 20$ & $5 \cdot 7 \pm 3.9$ & $84(+) \dagger$ & $32 \cdot 3 \pm 1 \cdot 5$ & $0(-)$ \\
\hline Anti $\mathrm{H}-2 \mathrm{KD} .1$ & $1: 20$ & $34 \cdot 0 \pm 2 \cdot 7$ & $1(-)$ & $7 \cdot 4 \pm 2 \cdot 0$ & $76(+)$ \\
\hline Anti Ia $1,2,3,7,15$ & $1: 20$ & $35 \cdot 7 \pm 3 \cdot 0$ & $0(t)$ & $27 \cdot 5 \pm 1 \cdot 0$ & $12(+)$ \\
\hline $\mathrm{R}$ anti-MIg & $1: 20$ & $33 \cdot 2 \pm 2.5$ & $4(+)$ & ND & \\
\hline
\end{tabular}

* Indicator cells: Ox red blood cells (ORBC) coated with rabbit anti-ORBC.

$\dagger(+)$ or $(-)$ indicates the reaction predicted on the basis of CDL testing of lymph node cells from these strains with these sera.

Table 4 shows the results of similar studies testing normal and 'activated' peritoneal cells, which are composed chiefly of macrophages. Antisera against $\mathrm{K}$ and $\mathrm{D}$ antigens produced marked inhibition of the EA-RFC whereas anti-Ia produced comparatively little inhibition. It should be noted, however, that with activated macrophages the inhibition with anti H-2K and H-2D was considerably less than observed with other types of Fc receptor bearing cell types. This confirmed previous observations that activated macrophages were relatively resistant to inhibition by anti H-2 sera. (Kerbel, 1975, submitted for 
TABLE 4. Inhibition of EA-RFC from different tissues: peritoneal cells

\begin{tabular}{|c|c|c|c|c|c|}
\hline \multirow[b]{2}{*}{ Antiserum } & \multicolumn{5}{|c|}{$\%$ Inhibition of EA rosette formation after treatment with antiserum * } \\
\hline & $\mathrm{BALB} / \mathrm{c} \dagger$ & $\mathrm{B} 10 . \mathrm{A}(5 \mathrm{R})$ & $\mathrm{B} 10 . \mathrm{D} 2$ & A.TH & $\begin{array}{c}\text { B10.D2 } \\
\text { activated } \\
\text { peritoneal } \\
\text { cells } \ddagger\end{array}$ \\
\hline Anti H-2D.4, 13 & $76(+) \S$ & $81(+)$ & $67(+)$ & $67(+)$ & $28(+)$ \\
\hline Anti $\mathrm{H}-2 \mathrm{~K} .31$ & ND $\pi$ & ND & $78(+)$ & $-2(-)$ & $25(+)$ \\
\hline Anti $\mathrm{H}-2 \mathrm{~K} .33, \mathrm{Ia} .9$ & ND & $80(+)$ & $1(-)$ & $-1(t)$ & $9(-)$ \\
\hline Anti Ia $1,2,3,7$ & 14 & $25(+)$ & $-1(+)$ & $-5(-)$ & $-8(+)$ \\
\hline Rabbit anti MIg & $12(+)$ & ND & $19(+)$ & $\mathrm{ND}$ & 13 \\
\hline
\end{tabular}

* See footnote 1 , Table 3.

† The percentage of peritoneal cells which formed EA rosettes after treatment with normal serum (control) was: BALB $/ \mathrm{c} 40 \%$; B10.A(5R): 75\%; B10.D2: 75\%; A.TH: 57\%, 'activated' B10.D2 $=68.2$

$\ddagger$ Peritoneal cells induced by intraperitoneal injection of fetal bovine serum $48 \mathrm{hr}$ before harvesting. $\S$ See footnote 2, Table 3.

if $\mathrm{ND}=$ not done.

publication). The fact that a small and variable amount of inhibition of peritoneal RFCs was often seen after pretreatment with anti-Ia and anti-MIg sera presumably refiected the presence of some Ia positive and MIg positive peritoneal cells, respectively.

EA rosette formation by $\mathrm{P} 815 \mathrm{Y}$ mastocytoma tumour cells was strongly inhibited by anti $\mathrm{H}-2$ sera, as shown in Table 5 . Thus anti $\mathrm{H}-2 \mathrm{~K}$, or anti $\mathrm{H}-2 \mathrm{D}$ sera strongly inhibited EA rosette formation but anti-Ia had no effect.

In summary, antisera against $\mathrm{H}-2 \mathrm{~K}$ and $\mathrm{H}-2 \mathrm{D}$ antigens produced marked inhibition of EA rosette formation of spleen, lymph node, bone marrow, peritoneal macrophage, and tumour cells; only 'activated' macrophages were fairly resistant to such inhibition. Anti-Ia, in contrast, strongly inhibited spleen and lymph node EA RFC's (which are presumably Ia positive $B$ lymphocytes), but had little or no effect on bone marrow cells and peritoneal cells (which are largely Ia negative (McDevitt et al., 1974; Hämmerling et al., 1975), and P815Y

TABLE 5. Inhibition of EA-RFC from different tissues: P815Y*

\begin{tabular}{lrc}
\hline Pretreatment & $\%$ EA-RFC & $\%$ Inhibition \\
\hline NMS & $32 \cdot 0 \pm 2 \cdot 0$ & \\
Anti H-2D.4 & $7 \cdot 0 \pm 2 \cdot 5$ & $78(+) \dagger$ \\
Anti H-2K.8 & $6 \cdot 7 \pm 2 \cdot 3$ & $79(+)$ \\
Anti H-2D.13 & $3 \cdot 7 \pm 1 \cdot 7$ & $88(+)$ \\
Anti-Ia & $33 \cdot 0 \pm 1 \cdot 6$ & $0(+)$ \\
\hline
\end{tabular}

* P815Y mastocytoma tumour cells were maintained by serial peritoneal passage in DBA/2 mice but were removed prior to testing and cultured for $96 \mathrm{hr}$ in Falcon flasks to remove adherent cells.

† See footnote 2, Table 3. 
tumour cells [which are Ia negative (Halloran et al., 1975)]. Anti MIg reacted in a fashion simllar to anti Ia against bone marrow and peritoneal cells. These results supported the hypothesis that the inhibition of EA rosettes by antibody against a particular antigen seemed to reflect the ability of the antibodies to bind to surface antigens of the rosette forming cell, and did not imply a unique relationship of the antigens with the $\mathrm{Fc}$ receptor itself. Such results support the use of rosette inhibition to study the surface antigen expression on RFC.

(b) Cytotoxicity inhibition studies. Our published studies on the inhibition of antibodydependent cellular cytotoxicity (ADCC) by alloantibody showed that the antibody bound to cells in the incubation mixture resulting in antibody-cell complexes, which competed with the antibody-coated target cell for available $F c$ receptors on cytotoxic effector cells, inhibiting cytotoxicity. Anti H-2D, anti H-2K or anti-Ia sera could mediate this inhibition, presumably because all of these antigens were represented in the spleen cell population used as effector cells. It was therefore of interest to test other types of tissue as sources of effector cells, such as bone marrow or peritoneal cell preparations, since the composition of these cell populations is strikingly different from that of spleen cells. Preliminary experiments established the cell numbers required from each source to give equivalent degrees of cytotoxicity at $18 \mathrm{hr}: 10^{6}$ spleen cells, $2.5 \times 10^{5}$ bone marrow cells, and $2.5 \times 10^{5}$ peritoneal cells. We compared the inhibition of cytotoxicity by various anti $\mathrm{H}-2$ antisera using spleen, bone marrow and peritoneum as the source of the cytotoxic effector cells.

The results (Table 6) show that anti H-2K, H-2D and Ia gave strong and specific inhibition of cytotoxicity whether the effector cells were spleen cells, bone marrow cells, or peritoneal cells. The inhibition of each of these effector cell populations by anti-Ia sera presumably reflects the presence of at least some Ia positive cells in each of these tissues, since as few as $5 \%$ antigen positive cells have been shown to be detected in cytotoxicity

TABLE 6. Inhibition of ADCC mediated by cells from different tissue origin

\begin{tabular}{lccccccccc}
\hline & \multicolumn{1}{c}{ Inhibitory antiserum } & \multicolumn{3}{c}{ \% Inhibition of antibody dependent cytotoxicity using } \\
different effector cells *
\end{tabular}

* Target cells: $2 \times 10^{4}{ }^{51} \mathrm{Cr}$-labelled CRBC; anti-target cell antibody (RACA) $1: 50$ 000; effector cells: $10^{5}$ spleen cells or $2.5 \times 10^{5}$ bone marrow cells or $2.5 \times 10^{5}$ peritoneal cells; inhibitory antibody $1: 200$; incubation time: $18 \mathrm{hr}$; the specific ${ }^{51} \mathrm{Cr}$-release in absence of inhibitory antibody varied with the different effector cells between $20 \%$ and $37 \%$. The specificity control for anti Ia 1, 2, 3, 7, 15 (A.TH spleen cells) showed no inhibition of cytotoxicity.

$\dagger$ The relative weakness of the reaction of this serum with B10 macrophages and bone marrow cells presumably reflects the presence of only one specificity (Ia, 3) reacting with B10 cells, compared with two (Ia, 7, 15) reacting with B10.D2 cells. Other factors (differences in representation of different Ia specificities in each tissue) might also be operative. 
inhibition (Halloran et al., 1974). But since the number of Ia antigen bearing cells in each of these tissues varies, particularly between spleen (40-55\%) and bone marrow (5-15\%) (McDevitt et al., 1974), we should be able to demonstrate differences between these tissues in the degree of inhibition by anti-Ia. To study this possibility, equal numbers of spleen and bone marrow cells were tested in the presence of anti-Ia, anti H-2D, or normal mouse serum. Since this represents an excess of effector cell activity for the bone marrow cells the magnitude of inhibition was reduced, but the relative inhibition by anti-Ia compared to anti H-2D could still be assessed. As shown in Fig. 2, the amount of inhibition by the anti-Ia

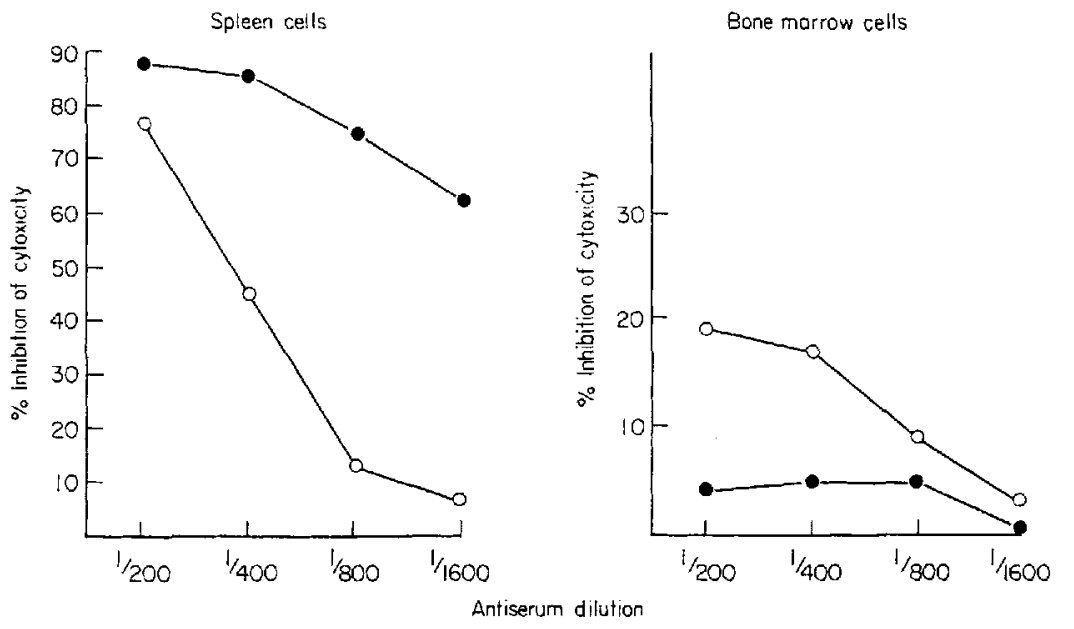

Frg. 2. Comparison of cytotoxicity inhibition by antisera anti H-2D.4 (O) and anti-Ia 1, 2, 3, $7,15(\bullet)$ using spleen and bone marrow effector cells. Although the magnitude of the inhibition of the bone marrow cells was less than that of spleen (note different scale) the altered order of the potency of the antisera is clearly shown. The $18 \mathrm{hr}$ ADCC protocol was used (see methods).

relative to the anti H-2D was much higher for the spleen cells, which have many la positive cells, than for bone marrow cells. Thus the cytotoxicity inhibition results reflected both the qualitative and quantitative antigen representation in a particular effector cell population.

Furthermore, the relative amount of antigen in any cell population (whether or not effector cells were present) could be assessed by simply adding those cells, after preincubation with the appropriate antiserum, as third party ('inhibitor') cells. We applied this technique to the question of the amount of Ia on thymocytes relative to the amount of Ia on lymph node lymphocytes. As shown in Fig. 3 thymocytes or lymphocytes after pre-incubation in NMS or in anti H-2D or anti-Ia serum were added to the standard cytotoxicity system. The degree of inhibition observed showed that while Ia was greatly reduced on thymocytes compared to lymphocytes, it was still definitely expressed on them, confirming previous findings (David et al., 1973; Frelinger et al., 1974) about the presence of Ia on thymocytes.

\section{DISCUSSION}

The mapping of the $\mathrm{H}-2$ antigens capable of mediating the inhibition of EA rosettes by antibody has been previously reported, (Halloran et al., 1975) and is further documented 


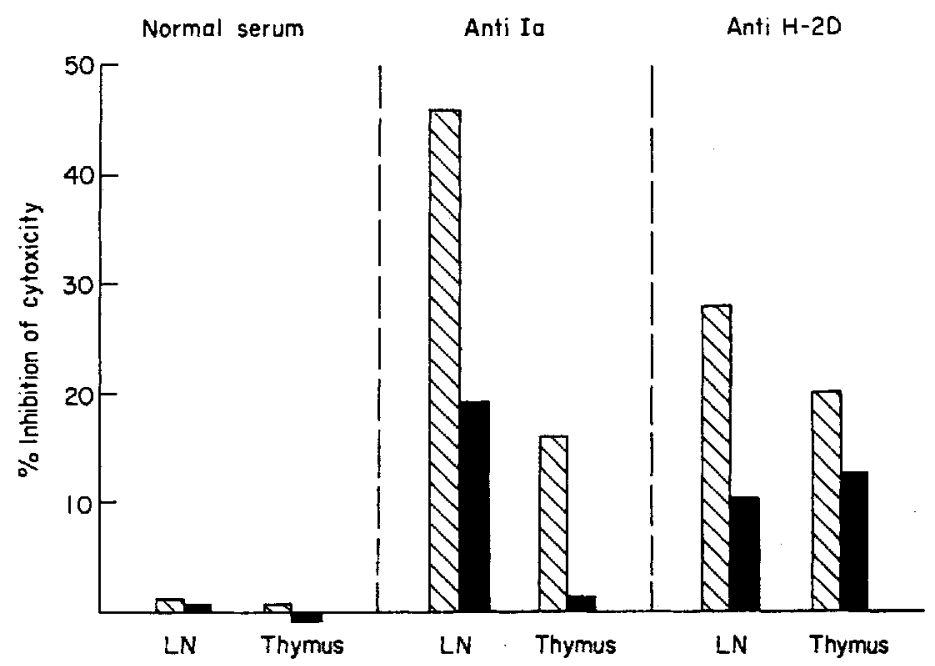

FIG. 3. Quantitative comparison of Ia antigen expression on thymus and lymph node cells. Thymocytes or lymph node cells $\left(10^{7} / \mathrm{ml}\right)$ were incubated at room temperature in anti-Ia, 1,2 , $3,7,15(1 / 50)$ or anti H-2D.4, $13(1 / 50)$ for $30 \mathrm{~min}$. The cells were then washed twice and added to the standard $18 \mathrm{hr}$ cytotoxicity protocol (see methods) at either $5 \times 10^{5} /$ tube (hatched bars) or $1.25 \times 10^{5} /$ tube (solid bars).

here. Thus anti $\mathrm{H}-2 \mathrm{~K}$, anti-Ia, and anti $\mathrm{H}-2 \mathrm{D}$ have all been shown to inhibit, and in the case of $\mathrm{H}-2 \mathrm{~K}$ the antigens responsible seem to be identical to those on erythrocytes, i.e. the conventional $\mathrm{H}-2 \mathrm{~K}$ specificities. But the quantitative differences between various antisera in the degree of inhibition observed remains unexplained and could have important implications. Antisera raised against $\mathrm{H}-2 \mathrm{D}$ antigens (with no Ia activity) and antisera raised against Ia antigens (with no $\mathrm{H}-2 \mathrm{~K}$ or $\mathrm{H}-2 \mathrm{D}$ activity) seemed stronger than antisera against $\mathrm{H}-2 \mathrm{~K}$ antigens (with no Ia activity). The relatively small number of sera tested in each group, and the unavailability of anti $\mathrm{H}-2 \mathrm{D}$ purified by the red cell absorption-elution process makes it difficult to draw definitive conclusions from these data, but certain possibilities can be entertained. The relative strength of the anti $\mathrm{H}-2 \mathrm{D}$ serum compared to the anti $\mathrm{H}-2 \mathrm{~K}$ serum, for example, could be due to antibody against serologically undetectable gene products in the $S$ or $G$ regions. Evidence from other lines of investigation support the possibility of unsuspected activities in antisera against $D$ end specificities (Arnaiz-Villeña et al., 1975). The difference between anti H-2K and anti-Ia, however, is more difficult to explain. Perhaps differences in the uniformity of distribution of $\mathrm{H}-2 \mathrm{~K}$ antigens compared to Ia antigens in the cell membrane could account for such differences (Schultz et al., 1975).*

Can we reconcile our data with those of Dickler \& Sachs (1974), which show convincingly that anti-Ia sera inhibit the binding of aggregated immunoglobulin to the B lymphocyte $\mathrm{Fc}$ receptor but anti $\mathrm{H}-2 \mathrm{~K}$ and $\mathrm{H}-2 \mathrm{D}$ do not? Several possibilities are beginning to emerge:

* The possibility that all of the inhibitory activity in anti $\mathrm{H}-2 \mathrm{~K}$ and anti $\mathrm{H}-2 \mathrm{D}$ sera is due to undiscovered Ia specificities can be discounted for reasons presented elsewhere (Halloran et al., 1975). Unsuspected activities against various regions may account for a portion of the quantitative strength of any of these antisera because the quantitative studies were not performed in recombinant mice. Indeed, the possibility of previously unrecognizable antibody specificities being detected in rosette inhibition is an intriguing subject for future exploration. 
one possibility is that the differences between anti-Ia and anti $\mathrm{H}-2 \mathrm{~K}$ or $\mathrm{D}$ is merely quantitative, but is seen more dramatically in the aggregate binding assay. The quantitative differences between $\mathrm{H}-2 \mathrm{~K}$ and Ia in our assay could support this view. A second possibility is that two mechanisms are operating in the inhibition of B lymphocyte EA rosettes: a 'non-specific' one which any antibody against cell surface antigens can mediate; and a 'specific' interaction between Ia antigens and Fc receptors. If so, perhaps only the specific mechanism can produce aggregate binding inhibition. Even if anti $\mathrm{H}-2 \mathrm{~K}$ and anti $\mathrm{H}-2 \mathrm{D}$ have no ability to block aggregate binding at all, a non $\mathrm{H}-2$ antigen is now reported by Dickler \& Sachs as inhibiting aggregate binding (Dickler, 1975) implying that Fc receptor inhibition is not unique to anti-Ia but is shared by other antibodies. Furthermore, recent studies have shown that the $\mathrm{Fc}$ receptor can be capped independently of Ia antigen (Pernis, 1975 personal communication; Unanue, 1975) indicating that no covalent linkage between Ia antigens and $F c$ receptors is possible. In spite of the fact that the mechanism of the inhibition of aggregate binding by antibody is still unresolved, this assay seems to be more selective for anti-Ia than is the rosette inhibition assay. It may, therefore, prove very useful as an operationally specific assay for antibody against Ia antigens in human and other species.

The inhibition of EA rosettes of bone marrow cells, macrophages, and tumour cells by anti H-2 sera can be predicted on the basis of the known tissue distribution of $\mathrm{H}-2 \mathrm{~K}, \mathrm{H}-2 \mathrm{D}$ and Ia antigens. Clearly, the $\mathrm{Fc}$ receptors on these cells are independent of Ia antigens. The observation, first made by Kerbel (1975), that 'activated' macrophages are inhibited much less than normal macrophages by anti $\mathrm{H}-2$ sera, was explained by him as being due to a decrease in the amount of $\mathrm{H}-2$ antigen on the surface of activated cells. An alternative explanation is found in the studies of Rhodes (1975) who documents that the Fe receptors of activated macrophages have a greatly increased activity for immunoglobulin.

The CIA provides a quantitative and $\mathrm{C}^{\prime}$ independent method of studying antigens on cells, without relying on cell destruction as an end point. The demonstration that bone marrow cells and peritoneal cells behaved similarly to spleen cells in the cytotoxicity inhibition system shows that the property of binding adjacent antibody-cell complexes, and thereby becoming inhibited, is not unique to spleen cytotoxic effector cells, but may be a property of all such cells. The experiment with thymocytes is one of several, all of which (with different Ia specificities) produced similar results indicating a significant amount of Ia antigen in thymus, a finding supported by some investigators (David et al., 1973; Hauptfeld et al., 1973; Götze et al., 1973; Frelinger et al., 1974; Lonai \& McDevitt, 1974) who find Ia on T cells or thymocytes, but disputed by others (Sachs \& Cone, 1973; Hämmerling et al., 1974). While not wishing to discuss this controversial issue at length, it would seem from studies of the percentage of EA-RFC in thymus $(<1.0 \%)$ that lymph node cell contamination of thymus preparations could not explain the observed degree of inhibition, since the amount of $B$ lymphocyte contamination required to account for the inhibition by anti-Ia would produce at least five times as many EA rosettes as we actually observed.

\section{ACKNOWLEDGMENTS}

The authors are grateful to Dr H. Festenstein for his advice and support, to Mrs V. Keeling for her assistance in antiserum preparation, and to Mrs M. Whiterow for secretarial assistance. 
This work was supported by the Medical Research Council of Canada, the Cancer Research Campaign, N.I.H. Grant A1 11962, and the Wellcome Trust Foundation.

\section{REFERENCES}

Arnaiz-Villeña, A., Halioran, P., David, C. \& Festenstein, H. (1975) Specific inhibition of lymphoid complement receptors by anti $\mathrm{H}-2$ sera: evidence for a new $\mathbf{H}-2$ linked polymorphism. Journal of Immunogenetics (in press).

David, C.S., Shreffler, D.C. \& Frelinger, J.A. (1973) New lymphocyte antigen system (Lna) controlled by $\mathrm{Ir}$ region of the mouse $\mathrm{H}-2$ complex. Proceedings of the National Academy of Sciences, United States of America, 70, 2509.

DAVID, C.S., STIMPFLING, J.H. \& SHREFFLER, D.C. (1975) Identification of specificity H-2.7 as an erythrocyte antigen: control by an independent locus, $\mathrm{H}-2 \mathrm{G}$, between the $\mathrm{S}$ and $\mathrm{D}$ regions. Immunogenetics, $2,131$.

Démant, P. (1973) The H-2 complex and its role in alloimmune reactions. Transplantation Reviews, 15, 162.

DICKLER, H. \& SACHS, D.H. (1974) Evidence for the identity or close association of the Fc receptor of B lymphocytes and alloantigens determined by the Ir region of the $\mathrm{H}-2$ complex Journal of Experimental Medicine, 140, 779.

DICKLER, H. (1975) In: Membrane receptors on Lymphocytes. (Ed. by M. Seligmann, J. L. Preud-Homme, \& F. Kourilsky).). North Holland Publishing Co. (in press).

Frelinger, J.A., Niederhuber, J.E., David, C.S. \& Shreffler, D.C. (1974) Evidence for the expression of Ia (H-2 associated) antigens on thymus-derived lymphocytes. Journal of Experimental Medicine, 140, 1273.

GötZE, D., Reisfeld, R.A. \& KLEIN, J. (1973) Serologic evidence for antigens controlled by the Ir region in mice. Journal of Experimental Medicine, 138, 1003.

Halloran, P. \& Festenstein, H. (1974) Inhibition of cell-dependent cytotoxicity as an assay for mouse alloantibody. Nature, 250, 52.

Halloran, P., Schtrrmacher, V. \& Festenstein, H. (1974) A new sensitive assay for antibody against cell surface antigens based on inhibition of cell-dependent antibody-mediated cytotoxicity. I. Specificity and Sensitivity. Journal of Experimental Medicine, 140, 1348.

Halloran, P., Schirrmacher, V. \& David, C.S. (1975) The specificity and significance of the inhibition of Fc receptor binding by anti H-2 sera. Immunogenetics, 2, 349.

Hämmerling, G.J., Deak, B.D., Mauve, G., Hämmerling, U. \& McDevitr, H.O. (1974) B lymphocyte alloantigens controlled by the I region of the major histcompatibility complex in mice. Immunogenetics, 1,68 .

Hämmerling, G.J., Mauve, G., Goldberg, E. \& McDevitt, H.O. (1975) Tissue distribution of Ia antigens: Ia on spermatozoa, macrophages and epidermal cells. Immunogenetics, 1, 428.

HauptFeld, V., KLEIN, D. \& KLeIN, J. (1973) Serological identification of an Ir-region product. Science, 181, 167.

KeRBEL, R.S. (1975) A marker for activated macrophages based on resistance of Fc rosette formation to inhibition by anti $\mathrm{H}-2$ antibodies (submitted for publication).

KLein, J., HauptFeld, V. \& HauptFeld, M. (1975) Evidence for a fifth (G) region in the H-2 complex of the mouse. Immunogenetics, $2,14$.

LoNAI, P. \& MCDeVIT, H.O. (1974) I-region genes are expressed on T and B lymphocytes. Studies of the mixed lymphocyte reaction (MLR). Journal of Experimental Medicine, 140, 1317.

McDevitt, H.O., Bechtol, K.B., Hämmerling, G.J., Lonal, P., \& Delovitch, T.L. (1974) Ir genes and antigen recognition. In: The Immune System: Genes, Receptors and Signals. (Ed. by E. E. Sercarz, A. R. Williamson, \& C. F. Fox). p. 597. Academic Press, New York.

PernJs, B. (1975) Personal communication.

RHODES, J. (1975) Macrophage heterogeneity in receptor activity: the activation of macrophage Fc receptor function in vivo and in vitro. Journal of Imminology, 114, 976.

SACHS, D.H. \& CONE, J.L. (1973) A mouse B lymphocyte alloantigen determined by gene(s) linked to the major histocompatibility complex. Journal of Experimental Medicine, 138, 1289.

SANDERSON, A.R. (1965) Quantitative titration, kinetic behavior and inhibition of cytotoxic mouse isoantisera. Immunology, 9, 287. 
SchirRmacher, V. \& Halloran, P. (1975) Independence of Fc receptors and Ia antigens on a variety of cells including cytotoxic $\mathrm{K}$ cells. In: Membrane receptors on lymphocytes. (Ed. by M. Seligmann, J. L. Preud-Homme \& F. Kourilsky), p. 261. North Holland Publishing Co.

SChirRmaCher, V., Halloran, P. \& David, C.S. (1975a) Interactions of Fc receptors with antibody against Ia antigens and other cell surface components. Journal of Experimental Medicine, 141, 1201.

Schirrmacher, V., Halloran, P., Ross, E.M. \& Festenstein, H. (1975b) A new sensitive assay for antibody against cell surface antigens based on inhibition of cell-dependent antibody-mediated cytotoxicity. II. Mechanism. Cellular Immunology, 16, 362.

Schultz, J.S., Frelinger, J.A., KIM, S.K. \& Shreffler, D.C. (1975) The distribution of Ia antigens of the H-2 complex on lymph node cells by immunoferritin labelling. Cellular Immunology, 16, 125.

Shreffler, D.C. \& DAVID, C.S. (1975) The H-2 major histocompatibility function, and organization. Advances in Immunology, 20, 125.

SNell, G. (1968) Catalogue of mouse allantisera. Transplantation Immunology Branch publication. National Institute of Allergy and Infectious Disease, National Institutes of Health, Bethesda, Maryland.

Staines, V.A., Ashton, L.J., Cuthrertson, J.L., \& Davies, D.A.L. (1975) The detection of Ia antibodies in polyspecific $\mathrm{H}-2$ alloantisera absorbed with erythrocytes. (submitted for publication).

UNANUE, E.R. (1975) In: Membrane receptors on lymphocytes. (Ed. by M. Seligmann, J. L. Preud-Homme \& F. Kourilsky), p. 281. North Holland Publishing Co.

Wigzel, H. (1965) Quantitative titration of mouse anti $\mathrm{H}-2$ antibodies using $\mathrm{Cr}^{\mathrm{s}}$ labelled target cells. Transplantation, 3, 423. 